\title{
Characterization of transport and deposition of terrestrial organic matter in the southern North Sea using the BIT index
}

\author{
Lydie Herfort, ${ }^{1}$ Stefan Schouten, Jan P. Boon, Martijn Woltering, ${ }^{2}$ Marianne Baas, \\ Johan W. H. Weijers, and Jaap S. Sinninghe Damsté \\ Department of Marine Biogeochemistry and Toxicology, Royal Netherlands Institute for Sea Research (NIOZ), \\ P.O. Box 59, 1790 AB Den Burg, Texel, The Netherlands
}

\begin{abstract}
We have applied a recently introduced proxy, the BIT (branched and isoprenoid tetraether) index, to determine terrestrial organic matter (TOM) transport from the rivers Rhine and Meuse and their tributaries to the southern North Sea. This index is based on crenarchaeol, an isoprenoidal glycerol dialkyl glycerol tetraether (GDGT) predominantly derived from aquatic Crenarchaeota and branched GDGTs produced by soil bacteria. Up to $1.6 \mathrm{ng} \mathrm{L}^{-1}$ of branched GDGTs were measured in seawater, demonstrating the presence of TOM in the southern North Sea. BIT indices were inversely correlated with salinity, indicating that this TOM was recently supplied by rivers. The substantial amount of branched GDGTs $\left(35 \mathrm{ng} \mathrm{L}^{-1}\right)$ detected in river water and the high branched GDGT concentration measured in the water of a Swiss peat bog $\left(5,900 \mathrm{ng} \mathrm{L}^{-1}\right)$ suggest fluvial transport of branched GDGTs from peats and soils to the oceans. The high crenarchaeol concentration measured in river water $\left(4.4 \mathrm{ng} \mathrm{L}^{-1}\right)$ was probably derived from crenarchaeota living in rivers and organic material from soil and peat. The BIT index, $\delta^{13} \mathrm{C}$ value, and $\mathrm{C}: \mathrm{N}$ ratio of surface sediments deposited in the southern North Sea were compared to determine TOM deposition. BIT index $(0.07$ to 0.26$)$ and $\delta^{13} \mathrm{C}(-20.6$ to $-22.9 \%$ ) both showed substantial small-scale differences in TOM deposition in the southern North Sea, but this pattern was not obvious from the $\mathrm{C}: \mathrm{N}$ ratios. A good correlation was found between $\delta^{13} \mathrm{C}$ and branched GDGT concentrations, indicating that the absolute GDGT concentrations give additional information to the BIT index.
\end{abstract}

Rivers provide large amounts of organic carbon to the marine environment $\left(\sim 4 \times 10^{14} \mathrm{~g} \mathrm{C} \mathrm{yr}^{-1}\right.$; Schlesinger and Melack 1981) and are thus a key component of the global carbon cycle. Analysis of the terrestrial organic matter (TOM) buried in marine sediments is widely carried out to estimate the importance and fate of TOM in carbon cycling. In paleoenvironmental studies, determination of TOM transport can also provide useful information on, for example, the proximity of the continent, river fluxes, and wind strength. The distinction between organic carbon of marine and terrestrial origins is commonly made by analyzing the $\mathrm{C}: \mathrm{N}$ ratio and the ${ }^{13} \mathrm{C}$ content of bulk organic matter (Meyers et al. 1994). Numerous biomarkers derived from higher plants are also used as proxies for

\footnotetext{
${ }^{1}$ Corresponding author (Herfort@nioz.nl).
}

2 Present address: Large Lakes Observatory, University of Minnesota Duluth, 10 University Drive, Duluth, Minnesota 55812 .

\section{Acknowledgments}

We thank the officers, crew, and scientific party of the RV Pelagia and RV Alkor for their support during the cruises, Jort Ossebaar (NIOZ) for performing the TOC measurements, Karel Bakker (NIOZ) for determining the nutrient concentrations, Sharyn Crayford (NIOZ) for C : N ratio analyses, Jurgen van den Donker (NIOZ) for his help with river sampling and analyses, and Ellen Hopmans (NIOZ) for assistance and advice for the high-performance liquid chromatography-mass spectrometry analyses. Two anonymous referees and the editor provided helpful comments on a draft of this paper. This study is part of the LOICZ project supported by the Research Council for Earth and Life Science, with financial aid from the Netherlands Organisation for Scientific Research (NWO 014.27.003). tracing TOM input in marine sediments. However, several problems are inherent to both approaches (Hedges et al. 1997; Pancost and Boot 2004). For instance, the inconstancy of the $\delta^{13} \mathrm{C}$ values of phytoplanktonic organic matter and TOM (e.g., $\mathrm{C} 3$ vs. $\mathrm{C} 4$ vegetation) renders the estimation of the proportion of terrestrial to marine organic matter in sediments difficult. Similarly, the difference in degradation rates of terrestrial-derived and marine-derived compounds may lead to erroneous estimation of terrestrial input in marine settings. These shortcomings make accurate quantification of TOM input in marine environments challenging (Hopmans et al. 2004, and references therein; Pancost and Boot 2004). In fact, Hedges and coworkers (1997) highlighted the geochemical conundrum, whereby significant fluvial delivery of TOM is not associated with detection of high abundances of TOM in seawater and marine sediments. They suggested that either remineralization of TOM in marine settings is a rapid process or that traditional detection methods are not sensitive enough.

A novel proxy to assess the relative contribution of TOM in marine environments, the so-called BIT (branched and isoprenoid tetraether) index, was recently introduced (Hopmans et al. 2004). This proxy is based on the relative abundance of the membrane lipids of marine Archaea and terrestrial Bacteria. Instead of the traditional diacyl membrane lipids found in eukaryotes and other bacteria, these prokaryotes have unusual membrane lipids made of glycerol dialkyl glycerol tetraethers (GDGTs) (Weijers et al. 2006). Distinction between organic carbon of terrestrial and marine origin is possible because the membrane lipids of marine Archaea are made of isoprenoid GDGTs, 

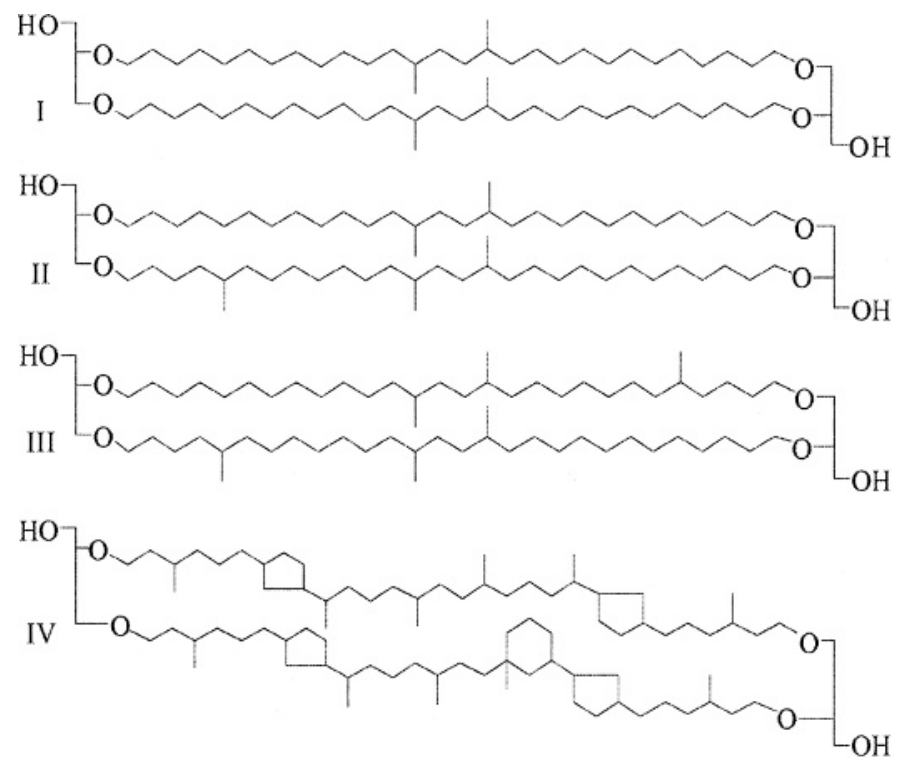

Fig. 1. Structures of the membrane lipids of marine Archaea and terrestrial Bacteria used for calculating the BIT index. Branched GDGTs are numbered I, II, and III; crenarchaeol is represented in structure IV.

whereas those of terrestrial bacteria are formed by branched GDGTs (Hopmans et al. 2004; Weijers et al. 2006). Crenarchaeol, an isoprenoid GDGT considered as a specific biomarker for the marine Crenarchaeota group I (Fuhrman et al. 1992; DeLong 1998) belonging to the archaeal domain (Schouten et al. 2000; Sinninghe Damsté et al. 2002; Powers et al. 2004), and the three most abundant branched GDGTs are used to calculate the BIT index (Hopmans et al. 2004):

$$
\mathrm{BIT}=[\mathrm{I}+\mathrm{II}+\mathrm{III}] /([\mathrm{I}+\mathrm{II}+\mathrm{III}]+[\mathrm{IV}])
$$

Numbers refer to the GDGT structures drawn in Fig. 1. According to the original definition of Hopmans et al. (2004), the BIT index values range from 0 , in sediments containing exclusively marine organic carbon, to 1 , in samples with no crenarchaeol and therefore comprising only terrigenous organic carbon. Like any other proxy, the GDGTs used to calculate the BIT index will be subject to early diagenesis, but as long as one of the compounds is not selectively degraded, a ratio of the two source biomarkers can provide information on the relative proportion of each molecule (see Hedges and Prahl 1993 for further details). Although comparative studies on the effect of early diagenesis on the GDGTs used for calculating the BIT index are still missing, the similarity in the structure of the branched and isoprenoid GDGTs suggests comparable diagenetic stability, hence possibly conferring an advantage to the BIT index compared to other molecular or bulk proxies for TOM input. In addition, crenarchaeol is found ubiquitously in marine sediments, while branched GDGTs are derived from seemingly ubiquitous bacteria living in peat and soil and are thus not selective for particular vegetation types or climatic regimes (Hopmans et al. 2004; Weijers et al. 2006).

The analysis of a large number of surface sediments originating from a wide range of environments has demonstrated the potential value of the BIT index in marine sediments (Hopmans et al. 2004). A more detailed study carried out on the surface sediments of the Angola Basin (eastern tropical Atlantic) clearly showed that contour plots of the BIT index reflected the Congo River outflow (Hopmans et al. 2004). The BIT index was also tested in the water column by analyzing suspended particulate organic matter at several stations in the southern North Sea (Hopmans et al. 2004). This showed that at two sites, high BIT index values were associated with low salinities. Although all these data suggest that the BIT index may be a promising proxy for assessing the relative contribution of TOM input to marine environments, further studies are required to get a better understanding of the constraints on the use of the BIT index as a proxy for TOM input into marine environments.

Here we report of the first study where TOM transport in seawater and deposition in sediments was determined by using the BIT index. The southern North Sea was selected as the main location for this work because of the large influence of West European and British rivers, its diverse hydrographical dynamics, and its generally low sedimentation rates. Because the Rhine/Meuse is the most important river system flowing into this area (de Kok 1996), water sampling was also carried out in these two rivers and their tributaries. In addition, because the branched GDGTs are presumably of soil and peat origin, measurements were also made in the surface water of a Swiss peat bog. Some of the factors influencing the BIT index are presented and compared with other commonly used proxies of TOM, i.e., $\delta^{13} \mathrm{C}$ and $\mathrm{C}: \mathrm{N}$ ratios.

\section{Materials and methods}

Southern North Sea-The southern North Sea is a shallow shelf sea (maximum depth of $50 \mathrm{~m}$, except for a few deeper parts) characterized by a predominant influence of coastal runoff and a strong interaction with the seafloor (Otto et al. 1990). This area is bordered in the east and south by the European continent and in the west by the British Isles. To the south, it is connected with the northeast Atlantic Ocean through the Strait of Dover; the Dogger Bank constitutes the northern boundary (Fig. 2). As a result of geomorphology, tidal motion, and prevailing southwesterly winds, seawater from the north enters the region southward along the British coast and through the Strait of Dover and flows out northward on the eastern side of the basin with the so-called Jutland current. This creates a counterclockwise residual current system where several water masses converge in the central part of the southern North Sea: central North Sea water, Channel water of recent oceanic origin, and continental and English coastal waters (Lee 1980) (Fig. 2). The latter two water masses are characterized by high freshwater input supplied by the main West European (essentially Rhine, Meuse, and Scheldt) and British (Thames, Humber, Tees, and Tyne) rivers. The Jutland current forces the freshwater discharged by the West European rivers to spread in a northeastern direction along the Dutch coast (Otto et al. 1990), whereas water from the rivers Thames and Humber stretches 
eastward with the East Anglian Turbidity Plume (Fig. 2). The interaction between hydrography and topography also leads to a lack of net sedimentation and associated burial in the study area (Eisma 1981; de Haas et al. 1997).

Rivers - The Rhine originates on the Gotthard Massif in Switzerland from a gathering of high-latitude small streams. The river flows through Lake Constance at the border of Germany, Austria, and Switzerland and meanders over a distance of $1,320 \mathrm{~km}$ before entering the southern North Sea through the "Nieuwe Waterweg" near Rotterdam and the sluices in the Haringvliet. With an average annual discharge of $2,300 \mathrm{~m}^{3} \mathrm{~s}^{-1}$ (de Kok 1996), together with the Meuse in a mixed estuary, the Rhine is the most important river flowing into the southern North Sea. The Meuse rises in the Langre plateau in France before flowing through Belgium and the Netherlands. The Niers takes its source in Germany and meets the Meuse at the border with the Netherlands. The Berkel also rises in Germany and after entering the Netherlands joins the Ijssel, a branch of the Rhine.

Peat bog-Etang de la Gruère, a raised bog area, is located in the Jura mountains of Switzerland. Branched GDGTs have been detected within this peat bog (Weijers 2006).

Water sampling-Sampling in the southern North Sea was carried out at eight stations (Fig. 2) during three CRENS cruises, with the RV Pelagia in February 2003 and April 2004 and with the RV Alkor in August/September 2004. Suspended particulate organic matter was collected by filtering $40 \mathrm{~L}$ of surface and bottom seawater onto preashed $0.7-\mu \mathrm{m}$ glass fiber filters. Those were kept frozen at $-20^{\circ} \mathrm{C}$ until analysis. Salinity values of seawater were obtained by using a conductivity-temperature-depth sensor. Sampling in the river Rhine was carried out in February and September 2005, midway between each bank, at three locations in the Netherlands: Maassluis (Nieuwe Waterweg, estuary of the Meuse/Rhine), Gorinchem (Boven-Merwede), and Millingen (Rhine, at the Dutch-German border) (Fig. 2). In mid-October 2005, water was sampled again at Millingen, but also in the Meuse at Bergen, in the Niers at Ottersum and in the Berkel at Lochem (Fig. 2). Suspended particulate organic matter was collected by filtering $5 \mathrm{~L}$ of river water onto preashed 3- and $0.7-\mu \mathrm{m}$ glass fiber filters. Those were kept frozen at $-20^{\circ} \mathrm{C}$ until analysis. The salinity values of the river water samples were measured by using a refractometer. In summer 2003, $1 \mathrm{~L}$ of surface water was gently collected from the Etang de la Gruère peat bog and was kept at $4{ }^{\circ} \mathrm{C}$ until return to our laboratory, where it was filtered onto preashed 3- and $0.7-\mu \mathrm{m}$ glass fiber filters and analyzed.

Sediment sampling - Surface sediments were obtained with a Royal Netherlands Institute for Sea Research box corer (maximum length, $55 \mathrm{~cm}, \varnothing 50 \mathrm{~cm}$ ) equipped with a closing lid. Overlaying bottom water was siphoned off and subsamples were taken by inserting three plastic liners. Those were stored upright at $-20^{\circ} \mathrm{C}$ pending analysis.

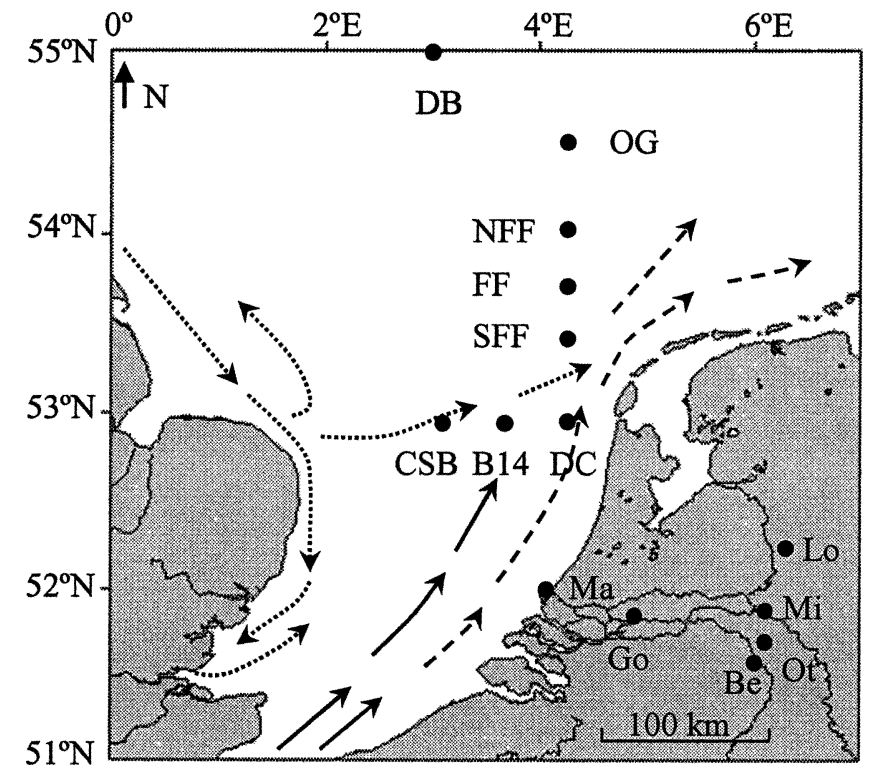

Fig. 2. Map showing location of study sites in the southern North Sea and in Dutch rivers. DC, Dutch Coast; CSB, Central Southern Bight; B14, Breeveertien; SFF, South Frisian Front; FF, Frisian Front; NFF, North Frisian Front; OG, Oyster Grounds; DB, Dogger Bank; Ma, Maassluis; Go, Gorinchem; Mi, Millingen; Be, Bergen; Ot, Ottersum; Lo, Lochem. Surface currents were reproduced from Lee (1980). Plain arrows, channel waters; dotted arrows, English coastal waters and the East Anglian Turbidity Plume; dashed arrows, Dutch coastal waters. The geographical position of Breeveertien was slightly modified to $52: 48 \mathrm{~N}$ and $3: 33 \mathrm{E}$ during the spring and summer cruises to ensure sampling in the correct water mass.

GDGT analysis-Freeze-dried filters were ultrasonically extracted three times with methanol, three times with dichloromethane (DCM)-methanol (1:1, v/v) and three times with DCM. All extracts were combined and salts were removed by shaking against water. Finely powdered and freeze-dried surface sediments $(0-1 \mathrm{~cm})$ were extracted three times with an Accelerated Solvent Extractor 200 (ASE 200, Dionex) with a mixture of DCM-methanol $(9: 1, \mathrm{v} / \mathrm{v})$ at high temperature $\left(100^{\circ} \mathrm{C}\right)$ and pressure $(7.6 \times$ $10^{6} \mathrm{~Pa}$ ). All samples (seawater and sediments) subsequently underwent similar treatments. After a drying procedure over a sodium sulfate column using DCM, total extracts were divided into apolar and polar fractions over an alumina oxide column using a mixture of hexane-DCM $(9: 1, \mathrm{v} / \mathrm{v})$ and methanol-DCM $(1: 1, \mathrm{v} / \mathrm{v})$, respectively, as eluent. Polar fractions were dried under nitrogen flow and dissolved by sonication in hexane-propanol $(99: 1$, v/v). This solution was filtered through an Alltech $0.45-\mu \mathrm{m}$ polytetrafluoroethylene filter (Ø $4 \mathrm{~mm}$ ). GDGTs were measured by high-performance liquid chromatography/ atmospheric pressure positive ion chemical ionization mass spectrometry according to Hopmans et al. (2004), except for modification in the scanning procedure, because single ion monitoring mode was used to increase the sensitivity and reproducibility of the detection $(\mathrm{m} / \mathrm{z} 1,302.3,1,300.3$, $1,298.3,1,296.3,1,292.3,1,050.0,1,036.0$, and 1,022.0 for the different GDGT isomers). 
Grain-size distribution and organic carbon content-Sediment grain-size distribution was measured by laser diffraction on a Coulter LS 230. Silt content (wt\%) was defined as the grain size fraction smaller than $63 \mu \mathrm{m}$. Total organic carbon (TOC) content of sediment was analyzed on finely powdered freeze-dried and carbonate free (after acidification) sediments with a Carbo Erba Flash Elemental Analyzer (1112 series, ThermoQuest).

Stable carbon isotope and $C: N$ ratios-Freeze-dried and decarbonated sediments were analyzed by elemental analysis/isotope-ratio-monitoring mass spectrometry (EA/ irmMS) with a Carbo Erba Flash Elemental Analyzer coupled to a Thermofinnigan DeltaPLUS irmMS system. Stable carbon isotope ratios are given in standard delta notation relative to the VPDB standard. Analyses of finely powdered freeze-dried and carbonate-free sediments for carbon and nitrogen content was done on a Thermo Flash Elemental Analyzer (1112 series) with acetanilide $\left(\mathrm{C}_{8} \mathrm{H}_{9} \mathrm{OH}\right)$ used as standard.

Nutrient concentrations - To determine nitrate and ammonium concentrations, $3 \mathrm{~mL}$ of freshly collected seawater was passed through a $0.2-\mu \mathrm{m}$ Acrodisc filter and analyzed with a segmented continuous flow analyzer (TRAACS 800 autoanalyzer, Bran and Luebbe).

\section{Results}

GDGT distribution in seawater-River discharge into seawater is characterized by the stratification of the water column in terms of salinity, temperature, and nutrient concentrations. Differences in these parameters between surface and bottom seawater were evident in February 2003 at the Dutch Coast, South Frisian Front, and Frisian Front (Table 1). At these stations differences in salinity and temperature between surface and bottom water ranged from 2.6 to 4.0 and from 1.8 to $2.2^{\circ} \mathrm{C}$. High variations in nutrient concentrations were also observed with, for example, 45.8 and $18.8 \mu \mathrm{mol} \mathrm{L}^{-1}$ of nitrate measured at the Dutch Coast in surface and bottom water, respectively.

Table 2 gives the salinity values, crenarchaeol and branched GDGT concentrations, and BIT indices that were measured at eight locations in the surface seawater of the southern North Sea in three different seasons. Differences in salinities were observed with variations from 29.7 to 35.0. Crenarchaeol was found at all sites and seasons, with values ranging from 0.1 to $6.9 \mathrm{ng} \mathrm{L}^{-1}$. However, the same is not true for the branched GDGTs because in some cases they could not be detected or were below the limit for accurate quantification $\left(<0.07 \mathrm{ng} \mathrm{L}^{-1}\right)$. When quantifiable, their concentration ranged from 0.1 to $1.6 \mathrm{ng} \mathrm{L^{-1 }}$. BIT indices were not determined when branched GDGTs were below the limit for accurate quantification. BIT index values varied from 0.02 to 0.25 (Table 2).

GDGT distribution in river water-Table 2 also gives the salinities, the branched GDGT and crenarchaeol concentrations, and the BIT indices of river water. Sampling was
Table 1. Characteristics of surface and bottom seawater measured in February 2003 at three sites in the southern North Sea showing vertical differences in terms of salinity, temperature, and nutrient concentrations. Station abbreviations are given in Fig. 2.

\begin{tabular}{lcccc}
\hline \hline Station & Salinity & $\begin{array}{c}\text { Temperature } \\
\left({ }^{\circ} \mathrm{C}\right)\end{array}$ & $\begin{array}{c}\text { Nitrate } \\
(\mu \mathrm{mol} \mathrm{L}-1)\end{array}$ & $\begin{array}{c}\text { Ammonium } \\
(\mu \mathrm{mol} \mathrm{L}-1)\end{array}$ \\
\hline DC & & & & \\
Surface & 29.7 & 3.9 & 46 & 3.0 \\
Bottom & 33.7 & 5.7 & 19 & 0.8 \\
SFF & & & 40 & 2.0 \\
Surface & 30.7 & 3.2 & 12 & 0.3 \\
Bottom & 34.4 & 5.4 & 31 & 1.4 \\
FF & & & 11 & 0.2 \\
Surface & 31.9 & 3.4 & & \\
Bottom & 34.5 & 5.5 & &
\end{tabular}

done at low tide, which is reflected by the low salinities $(0.5-1.9)$ that were recorded at most stations. The station Maassluis is located close to the outflow into the North Sea, and a slightly higher salinity (6.0) was measured at this site in September, suggesting the presence of seawater into the estuary. As expected, all samples contained high concentrations of branched GDGT (5.6-88 ng L-1), but surprisingly relatively high concentrations of crenarchaeol were also measured $\left(0.6-10.7 \mathrm{ng} \mathrm{L}^{-1}\right)$. The resulting BIT indices were nevertheless high, with values ranging from 0.74 to 0.95 . Seasonal variations were apparent in the Rhine at Millingen, with higher concentrations of crenarchaeol and branched GDGTs measured in February than in October. There were, however, no obvious seasonal differences in the BIT index. The presence of seawater into the estuary detected at Maassluis in September was associated with a decrease in the concentrations of crenarchaeol and branched GDGTs.

GDGT distribution in peat bog surface water-The concentrations of crenarchaeol and branched GDGT, and the BIT index of water that was collected on the surface of a Swiss peat bog are also provided in Table 2. Crenarchaeol could not be detected, but extremely high concentrations of branched GDGTs $\left(5,900 \mathrm{ng} \mathrm{L}^{-1}\right)$ were measured, giving rise to a BIT index value of 1 .

Bulk parameters of the southern North Sea surface sediments - The basic grain-size and organic carbon characteristics of surface sediments sampled at eight locations in the southern North Sea are presented in Fig. 3. The percentages of silt and TOC varied, with respective values ranging from 0 to $60 \%$ and from 0.02 to $0.42 \%$. Sandy sediments with very low silt contents were, as expected, always associated with low TOC values. The average stable carbon isotopic composition and the $\mathrm{C}: \mathrm{N}$ ratio of bulk organic carbon measured in the surface sediments of the southern North Sea are shown in Fig. 4. The $\delta^{13} \mathrm{C}$ values varied between sites from -20.6 to $-22.9 \%$, with slightly depleted values obtained at the Central Southern Bight, Frisian Front, North Frisian Front, Oyster Grounds, and Dogger Bank and relatively heavier values measured at the 


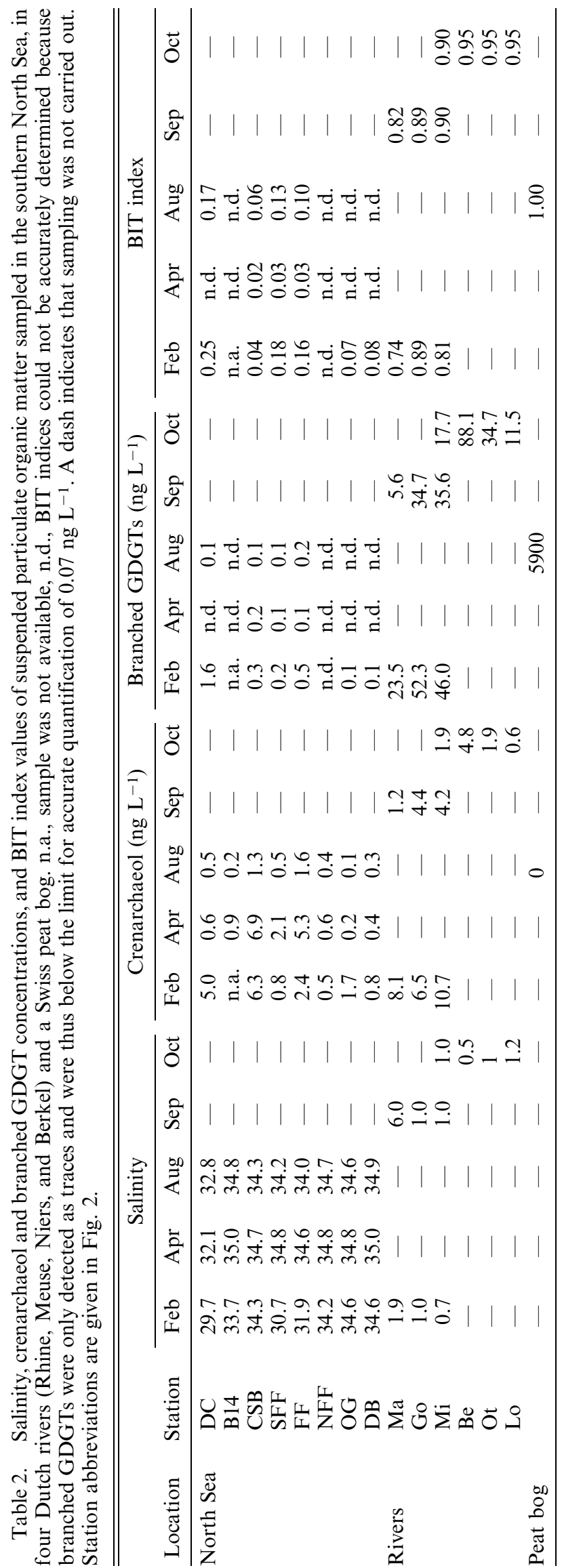

stations Dutch Coast, Breeveertien, South Frisian Front. The result of one-way analysis of variance (ANOVA) on the $\delta^{13} \mathrm{C}$ values of these two groups of stations were significant $\left(F=70.2, \mathrm{df}=1, p=2.7 \times 10^{-8}\right)$. In contrast, no significant patterns were observed for the $\mathrm{C}: \mathrm{N}$ ratios, which ranged from 8.2 to 11.0.

GDGTs and BIT index in sediments - Crenarchaeol and branched GDGTs were detected in surface sediments at all stations and seasons, with average values ranging from 8280 to $1-60 \mathrm{ng} \mathrm{g}^{-1}$ dry weight sediment, respectively. As mentioned above, high silt contents are always associated with elevated TOC values, so to remove this effect and thus to distinguish between high GDGT concentrations resulting from high TOC content from those derived from actual elevated GDGT input, the concentrations of all GDGTs were normalized to TOC (Fig. 5). The average BIT indices were calculated for each station and are also presented in Fig. 5. These sediments show little seasonal variations in the concentrations of crenarchaeol and branched GDGT and in their BIT indices.

Crenarchaeol concentrations varied between sites from 15 to $60 \mu \mathrm{g} \mathrm{g}^{-1} \mathrm{TOC}$, with low concentrations measured at the stations Dutch Coast, Breeveertien, South Frisian Front, and Dogger Bank and higher concentrations found at the Central Southern Bight, Frisian Front, North Frisian Front, and Oyster Grounds. The result of one-way ANOVA on the crenarchaeol concentrations of these two groups of stations were significant $(F=56.7, \mathrm{df}=1, p=$ $1.59 \times 10^{-7}$ ). Differences were also observed for the branched GDGTs with concentrations ranging from 1.5 to $16 \mu \mathrm{g} \mathrm{g}^{-1}$ TOC. Similarly to crenarchaeol, low concentrations of branched GDGTs (1.5-2.2 $\mu \mathrm{g} \mathrm{g}^{-1}$ TOC) were measured at the Dutch Coast, Breeveertien, and South Frisian Front, while higher concentrations (4.4-15.6 $\mu \mathrm{g} \mathrm{g}^{-1}$ TOC) were found at the Central Southern Bight, Frisian Front, North Frisian Front, and Oyster Grounds. With a value of $3.5 \mu \mathrm{g} \mathrm{g}^{-1}$ TOC, the Dogger Bank lays in between these two groups of stations. The highest statistical difference between sites with low and high concentrations of branched GDGTs was, however, obtained when the Dogger Bank was associated with the sites containing low concentrations of branched GDGTs (one-way ANOVA; $F$ $\left.=15.7, \mathrm{df}=1, p=6.5 \times 10^{-4}\right)$. BIT indices also differed between stations, spanning from 0.08 to 0.27 , but did not show a difference between sites with low and high GDGT concentrations $(F=1.5$, df $=1, p=0.22)$. Relatively higher BIT indices were, however, calculated for the Central Southern Bight and the Dogger Bank. The result of one-way ANOVA confirmed that the BIT indices of these two stations were significantly different from the others $\left(F=56.6, \mathrm{df}=1, p=1.6 \times 10^{-7}\right)$.

\section{Discussion}

TOM transport-BIT index as tracer for TOM input into seawater: Haline stratification, after incomplete mixing of river input into seawater, was observed in our study as illustrated by the differences in salinity, temperature, and nutrient concentrations that were recorded between surface 

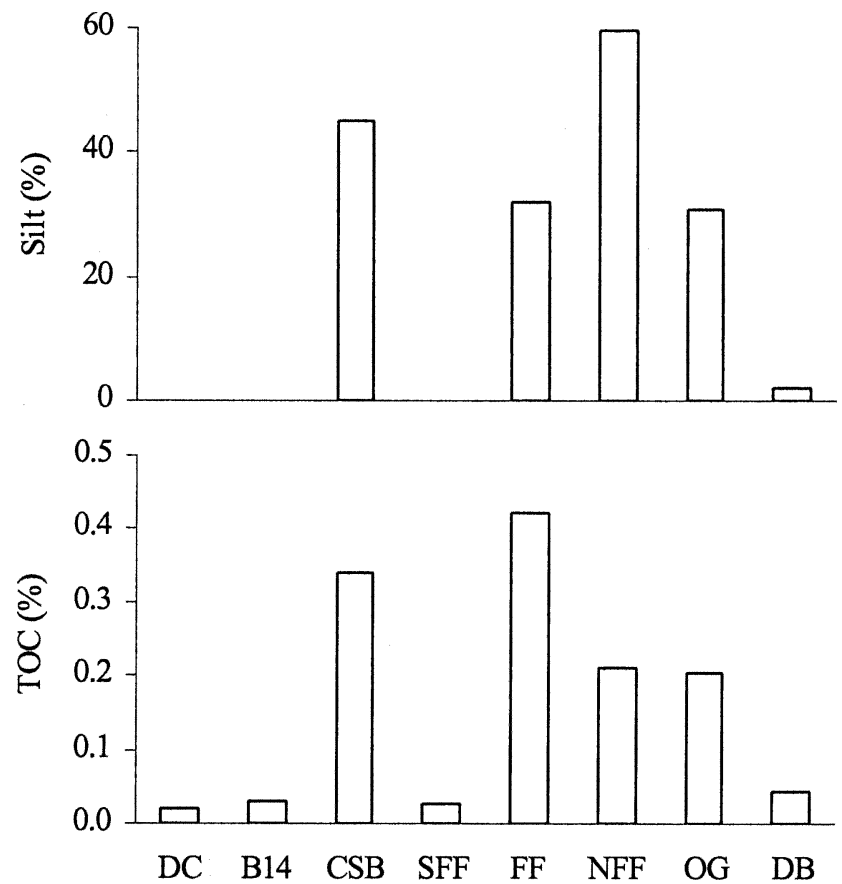

Fig. 3. Percentage of silt and TOC of surface sediments sampled at eight locations in the southern North Sea. Station abbreviations are given in Fig. 2 .

and bottom waters at several stations (Table 1). In good agreement with the known discharge patterns of the main rivers flowing in this area, seasonal differences in salinity were observed in surface seawater. Freshwater from the Thames and Humber is transported with the East Anglian Turbidity Plume from the English coast across the Southern Bight at a latitude of about $53^{\circ} \mathrm{N}$ (Fig. 2). It is characterized by a seasonal cycle with supply of fine particles in winter and transient deposition during summer (Dyer and Moffat 1998). The Central Southern Bight, a site situated midway between the Netherlands and England at $3^{\circ} \mathrm{E}$, is located directly in the path of the East Anglian Turbidity Plume and lower salinity than that of the Channel water was thus expected at this station in February. However, strong westerly winds had shifted the position of the plume toward the South Frisian Front and Frisian Front, where low surface water salinity values were recorded (Table 1). As anticipated, the East Anglian Turbidity Plume was less strong during the subsequent spring and summer cruises. Similarly, large discharges from the Rhine and associated density fronts occur predominantly in winter and early spring (Visser et al. 1991). This too was evident in our study because the lowest salinity value was measured in February at the Dutch Coast, a site located within the river Rhine coastal jet (Tables 1 and 2). During subsequent cruises river input was also detected at this station but was rather less pronounced (Table 2).

It is well accepted that the southern North Sea is strongly influenced by river discharges, but several studies have suggested that the resulting high freshwater input is not associated with important TOM addition to the marine environment (Salomons and Mook 1981; Megens et al.
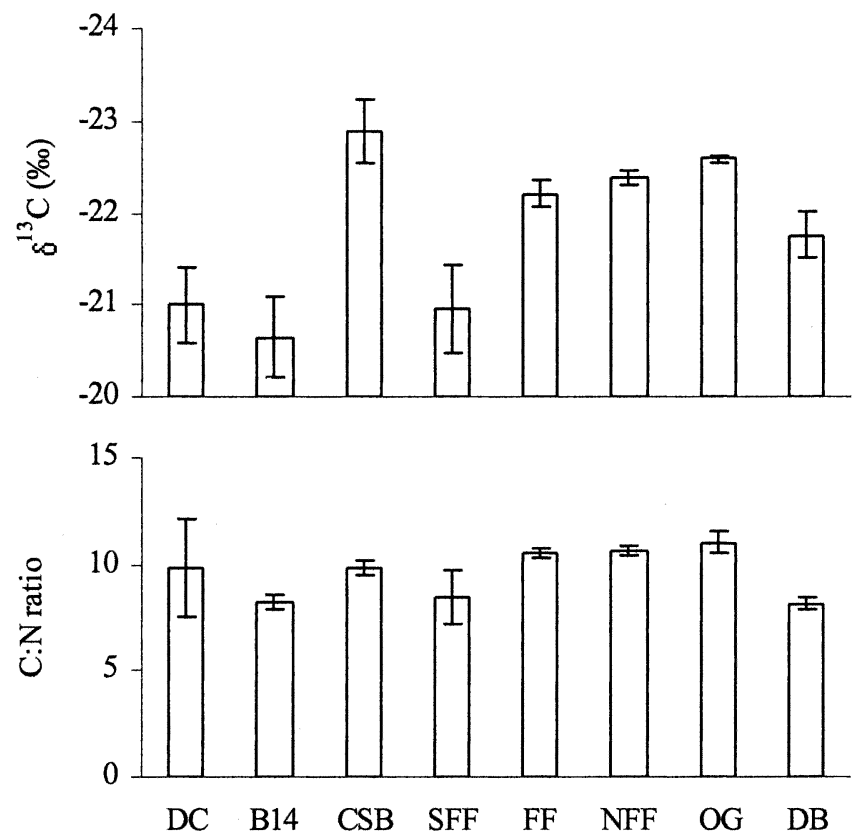

Fig. 4. Stable isotopic composition and the $\mathrm{C}: \mathrm{N}$ ratio of bulk organic carbon measured in the surface sediments of the southern North Sea. Error bars represent the standard deviation calculated from data obtained in February 2003, April 2004, and August 2004. Station abbreviations are given in Fig. 2.

2001). Clearly, the detection of branched GDGTs in suspended particulate organic matter in surface seawater demonstrates the presence of TOM in the southern North Sea. Figure 6 presents the plot of salinity values against BIT indices and clearly shows that they are negatively correlated, with higher BIT indices associated with lower salinity values. This suggests that the branched GDGTs, and therefore, TOM detected in the seawater was recently supplied to the marine environment by rivers, indicating that the BIT index may be a good proxy for assessing TOM input into seawater.

BIT index in river water: To verify the assumption that the branched GDGTs detected in marine environments are transported by rivers to the sea, sampling of suspended particulate organic matter was also carried out at three locations in the river Rhine. This confirmed that low salinities were associated with high concentrations of branched GDGT as those were very abundant in the Rhine water (Table 2), with an average of $30 \mathrm{ng} \mathrm{L}^{-1}$, which is 20 times higher than the largest concentration measured in the southern North Sea (1.6 ng L-1; Table 2). To test whether these high concentrations of branched GDGTs are only characteristic of the Rhine or if they reflect a typical level for river water, sampling was also carried out in October 2005 in three rivers (Meuse, Niers, and Berkel) that have a different catchment area than the Rhine. The concentrations of branched GDGTs were also high in these rivers, with up to $88 \mathrm{ng} \mathrm{L}^{-1}$ measured in the Meuse at Bergen (Table 2). A relatively high branched GDGT concentration may thus be a typical feature of river water. Seasonal variations were, however, apparent in the Rhine at 

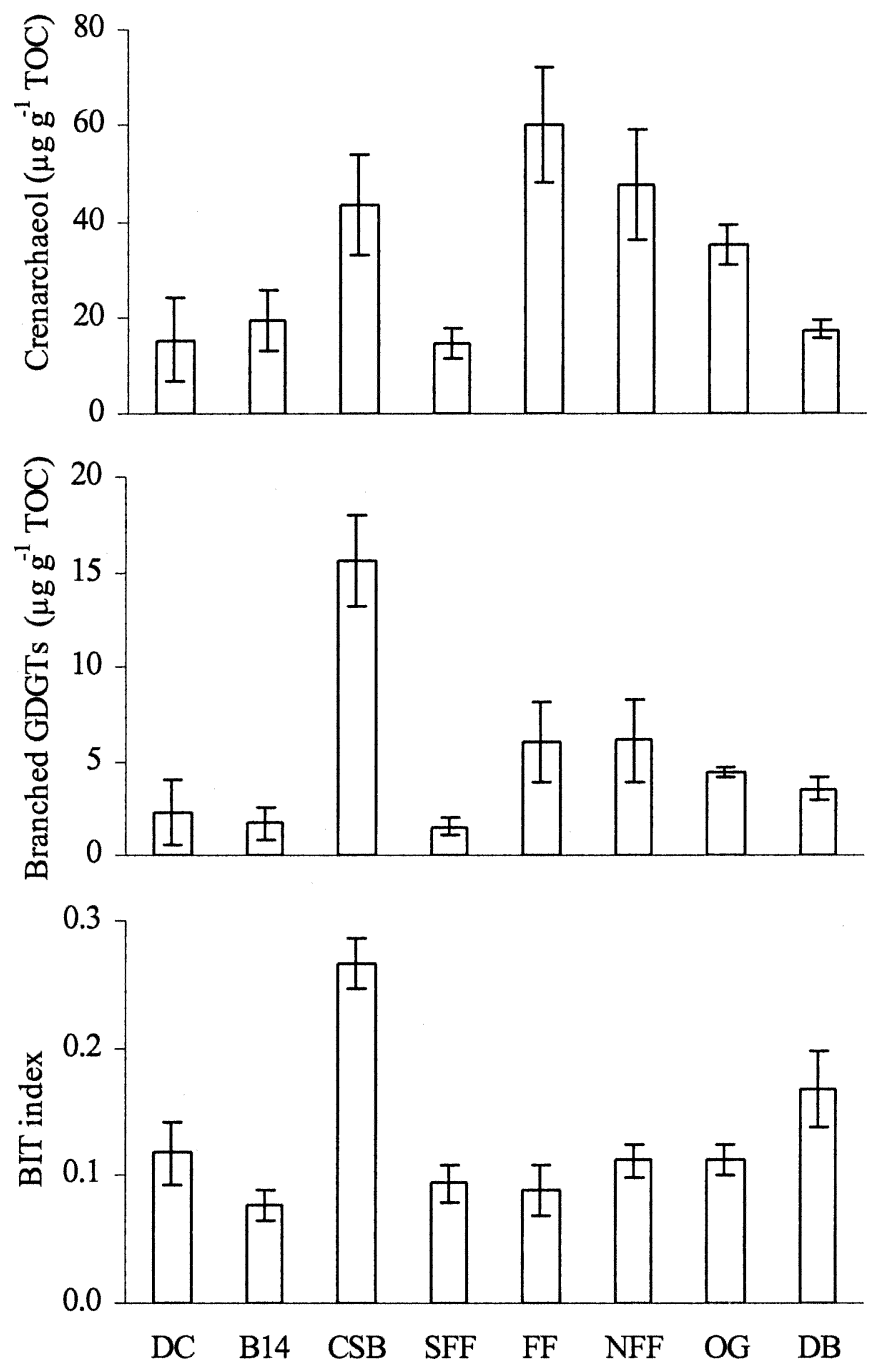

Fig. 5. Concentrations of crenarchaeol and branched GDGT, and BIT index values of surface sediments measured at eight stations in the southern North Sea. Error bars represent the standard deviation calculated from data obtained in February 2003, April 2004, and August 2004. Station abbreviations are given in Fig. 2.

Millingen, with higher values obtained in the winter than at the beginning of autumn. Given that runoff volume has been experimentally shown to be greater in winter than summer (Kwaad 1991; van Dijk and Kwaad 1996), this suggests that the amount of branched GDGTs present in rivers may be related to soil (and peat) erosion. This supports the idea that branched GDGTs are not produced in rivers, but transported to the rivers, although we cannot exclude until they are properly identified that the anaerobic bacteria synthesizing these branched GDGTs may also live in rivers. However, branched GDGT concentrations were two orders of magnitude higher $\left(5,900 \mathrm{ng} \mathrm{L}^{-1}\right.$; Table 2) in the surface water of a Swiss peat bog than in river water, thus strongly suggesting that the anaerobic bacteria producing these branched GDGTs thrive in peats and ostensibly that branched GDGTs are transported from peats and soils to the oceans via rivers.

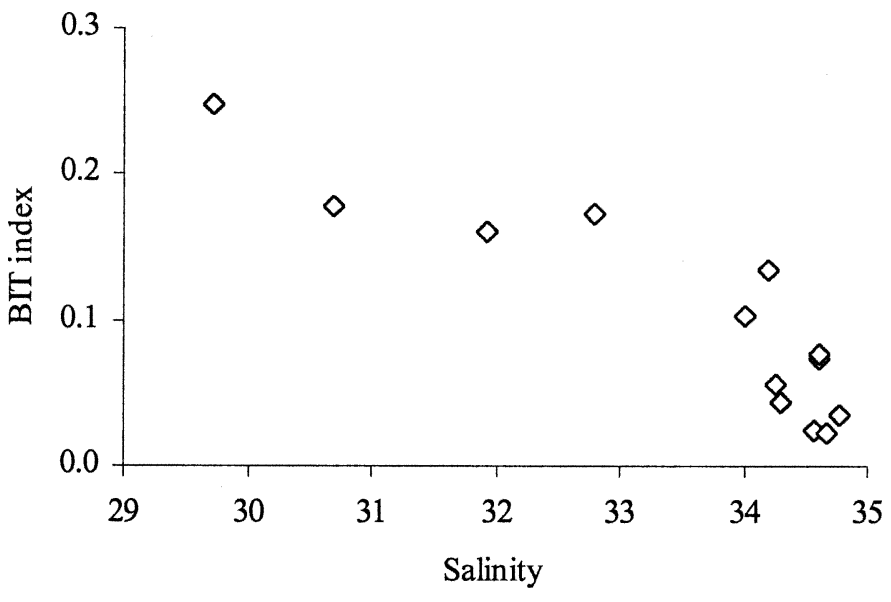

Fig. 6. Plot of salinity values against BIT indices of surface seawater in the southern North Sea.

Despite being much lower than that of branched GDGTs, the concentration of crenarchaeol measured in the four rivers sampled (average of $4.4 \mathrm{ng} \mathrm{L}^{-1}$; Table 2) was also greater than the average crenarchaeol concentration found in the southern North Sea during the three cruises (average of $1.7 \mathrm{ng} \mathrm{L}^{-1}$; Table 2) and only slightly lower than the highest value obtained in the seawater (6.3 $\mathrm{ng} \mathrm{L}^{-1}$; Table 2). This result was surprising because it is well known that group I Crenarchaeota, the subgroup of marine Archaea that produces crenarchaeol (Sinninghe Damsté et al. 2002), are abundant in marine environments (Karner et al. 2001; Herndl et al. 2005) but less so in soils and peats (Weijers et al. 2004). Two stations, Maasluis and Gorinchem, are situated close to the estuary, and although sampling was carried out at low tide as reflected by the low salinities, seawater intrusion cannot be ruled out at these sites. In contrast, Milligen, Bergen, Ottersum, and Lochem are all beyond the influence of seawater, thus confirming that the high crenarchaeol concentration found in river water does not result from mixing of seawater with river water.

It is feasible that this high signal is produced by Crenarchaeota living in the river itself. Several studies have indeed reported the existence of Crenarchaeota in rivers (Crump and Baross 2000; Abreu et al. 2001; Wells et al. 2006). However, molecular analysis of our samples did not reveal higher Crenarchaeota abundance in the Rhine than in the southern North Sea, and in fact Euryarchaeota were dominating the archaeal community at all riverine sites for all seasons (Herfort et al. unpubl. data). This implies that the Crenarchaeota living in river water cannot account alone for the high crenarchaeol concentrations measured in our rivers. Crenarchaeol has also been detected in the surface sediments of a large number of lakes distributed all over the world (Powers et al. 2004). The high concentration of crenarchaeol that was measured within the Rhine may thus be derived from the lacustrine Crenarchaeota communities of Lake Constance. However, the rivers Meuse, Niers, and Berkel do not flow through any large lake and yet a high crenarchaeol concentration 
was also measured in their water. This implies that the relatively high lipid signal measured in river water is not primarily derived from dead organic material originating from lacustrine Crenarchaeota communities. Given that crenarchaeol has been detected, albeit in much lower concentrations than branched GDGTs, in a Swedish peat bog and in a wide variety of soils (Weijers et al. 2004, in press) and that seasonal differences in crenarchaeol concentrations have been measured at Millingen, it is possible that these high crenarchaeol concentrations may be derived in part from crenarchaeota living in the rivers (in water and/or sediments) but also from dead material from soil and peat erosion. Further studies will be necessary to determine precisely the extent of each contribution and to assess seasonal and spatial variations in more detail.

The resulting BIT indices in river water were high at all stations (Table 2), with an average value of 0.88 that was substantially higher than the highest value obtained in the southern North Sea (0.25; Table 1). It is, however, important to note that the relatively high crenarchaeol concentration measured in rivers resulted in a BIT index below the theoretical terrestrial value of 1 proposed by Hopmans et al. (2004). This was not a seasonal effect as all measurements gave BIT indices below 0.95 . When the BIT index was originally computed, Hopmans et al. (2004) did not have any data on the concentrations of crenarchaeol and branched GDGTs in rivers. Our data show that despite being a terrestrial environment, rivers have a BIT index substantially smaller than 1 . This agrees with recent findings by Weijers et al. (in press), who calculated the BIT indices of soils from widely distributed locations and found an average of 0.91 , with some top soil values as low as 0.51 . Clearly, BIT index values below 1 are also found in terrestrial environments. This emphasizes that, as previously stressed by Hopmans et al. (2004), this new proxy gives a relative measure of TOM transport and should not be used as an absolute quantity. This also implies that instead of the originally defined range of the BIT index from $0-1$, it would be more accurate to have a narrower range from $0-0.1$ (dominated by marine organic matter) to 0.8-1 (dominated by TOM). Considering the potential effects of, for instance, variations in precipitation and thus river flow, remobilization of soils, or even dissimilarities between rivers from very different geographical areas, the riverine BIT index may need to be determined first in order to provide accurate relative estimates of TOM input in coastal marine sediments.

TOM deposition - With an average of $-21.8 \%$, the $\delta^{13} \mathrm{C}$ values of bulk organic carbon measured in the surface sediments of the southern North Sea were characteristic of marine settings (Hedges et al. 1997) (Fig. 4). Slightly depleted values were, however, found at the Central Southern Bight, Frisian Front, North Frisian Front, and Dogger Bank, possibly suggesting a larger terrestrial contribution to the sedimentary organic matter at these sites. A number of variables control the $\delta^{13} \mathrm{C}$ values of organic matter, including the TOC composition. In fact, it is well known that the $\delta^{13} \mathrm{C}$ of organic matter tends to become depleted in ${ }^{13} \mathrm{C}$ with low TOC sediments as severe oxic diagenesis selectively removes ${ }^{13} \mathrm{C}$-rich organic matter (Prahl et al. 1997; Hoefs et al. 1998). So, given the low TOC content of some of our sites (Fig. 3), $\delta^{13} \mathrm{C}$ data were compared with those obtained with the analysis of the $\mathrm{C}: \mathrm{N}$ ratio. With an average value of 9.6 , the $\mathrm{C}: \mathrm{N}$ ratios were also typical of marine sediments (Hedges et al. 1997), but in contrast with the $\delta^{13} \mathrm{C}$ values, they did not vary between sites (Fig. 4). This discrepancy highlights the uncertainties that are associated with these methods for determining TOM input.

These traditionally used proxies were then compared to the BIT index. Crenarchaeol and branched GDGTs were detected in surface sediments at all stations and seasons, and gave BIT indices ranging from 0.08 to 0.27 (Fig. 5). These values indicate predominantly marine organic matter and are thus in agreement with the $\delta^{13} \mathrm{C}$ and $\mathrm{C}: \mathrm{N}$ ratios. However, substantial small scale differences in TOM deposition in the southern North Sea were noticeable in the BIT index. This general pattern is in good accord with the $\delta^{13} \mathrm{C}$ results, but not with the $\mathrm{C}: \mathrm{N}$ ratios, suggesting that the latter is not a good proxy for TOM deposition in this area. Relatively high BIT indices were measured at the Central Southern Bight (0.27) and the Dogger Bank (0.17), suggesting terrestrial input, which is consistent with the $\delta^{13} \mathrm{C}$ analysis. This implies that the slightly depleted $\delta^{13} \mathrm{C}$ values obtained at these two sites were indeed probably representative of terrestrial input. In contrast, BIT index and $\delta^{13} \mathrm{C}$ analyses did not agree at the Frisian Front, North Frisian Front, and Oyster Grounds. The BIT indices of these stations were all below 0.1, thus refuting any idea of terrestrial influence. The relatively high branched GDGT concentrations detected at these three sites (Fig. 5) do, however, agree with the $\delta^{13} \mathrm{C}$ analysis and suggest terrestrial input. The "unexpected" low BIT index values obtained at these three sites are most likely the result of the high crenarchaeol concentrations found in their sediments (Fig. 5). In fact, the Frisian Front is recognized as an area of increased productivity (Creutzberg 1986; Cramer 1991; Boon and Duineveld 1998) with increased sedimentation rates $\left(0.1 \mathrm{~cm} \mathrm{yr}^{-1}\right.$; de Haas and Van Weering 1997). Water masses from the Southern Bight entering the deeper waters of the North create a drop of bottom current below critical values ( $25 \mathrm{~cm} \mathrm{~s}^{-1}$; Boon and Duineveld 1998) that enables fine grained particles to settle at this site. The Oyster Grounds has been described as a "mid-shelf temporary depocenter" where net annual sediment accumulation does not actually take place, but temporary settlement occurs (van Raaphorst et al. 1998). Van Raaphorst et al. (1998) have shown that most particles from the English coast are temporary deposited on the Oyster Grounds. Low crenarchaeol concentrations were measured in suspended particulate organic matter at this site (Table 2), suggesting that the high amount of crenarchaeol detected in surface sediments may also originate from elsewhere after many deposition-resuspension events. Alternatively, the discrepancy between $\delta^{13} \mathrm{C}$ values and BIT index at the Frisian Front may be the result of different $\delta^{13} \mathrm{C}$ values for marine organic matter at this site or of enhanced preservation of organic carbon (see above). In that case, the BIT index may 
be closer to the truth, i.e., there is a relatively low amount of terrestrial organic carbon at the Frisian Front.

The inconsistency between the BIT index and the other data (branched GDGT concentrations and $\delta^{13} \mathrm{C}$ values) illustrates that the extent of TOM deposition should not be determined by a single proxy, but rather by considering multiple proxies and, with regard to the BIT index, by also by using the absolute GDGT concentrations. It is nonetheless important to note that the southern North Sea is an extremely low depositional area, as clearly illustrated by the low TOC and silt contents (Fig. 3) and GDGT concentrations (Fig. 5) of the sediments analyzed in this study, and as such constitute a worst-case scenario for this type of analysis. In any case, the BIT index seems useful for assessing the relative contribution of TOM especially when used in combination with other proxies.

\section{References}

Abreu, C., G. Jurgens, P. De Marco, A. Saano, and A. A. Bordalo. 2001. Crenarchaeota and Euryarchaeota in temperate estuarine sediments. J. Appl. Microbiol. 90: 713718.

Boon, A. R., And G. C. A. Duineveld. 1998. Chlorophyll $a$ as a marker for bioturbation and carbon flux in southern and central North Sea sediments. Mar. Ecol. Prog. Ser. 162: 33-43.

Cramer, A. 1991. Benthic metabolic activity at frontal systems in the North Sea. Ph.D. thesis, Univ. of Utrecht.

Creutzberg, F. 1986. Distribution patterns of 2 bivalves species (Nucula turgida and Tellina fabula) along a frontal system in the southern North Sea. J. Sea Res. 20: 305-311.

Crump, B. C., And J. A. Baross. 2000. Archaeaplankton in the Columbia River, its estuary and the adjacent coastal ocean, USA. FEMS Microbiol. Ecol. 31: 231-239.

de HaAs, H., W. Boer, and T. C. E. Van Weering. 1997. Recent sedimentation and organic carbon burial in a shelf sea: The North Sea. Mar. Geol. 144: 131-146.

— AND T. C. E. VAN WeERING. 1997. Recent sediment accumulation, organic carbon burial and transport in the northeastern North Sea. Mar. Geol. 136: 173-187.

DE KoK, J. M. 1996. A two-layer model of the Rhine plume. J. Mar. Syst. 8: 269-284.

DeLong, E. F. 1998. Everything in moderation: Archaea as "nonextremophiles." Curr. Opin. Genet. Dev. 8: 649-654.

Dyer, K. R., And T. J. Moffat. 1998. Fluxes of suspended matter in the East Anglian plume Southern North Sea. Cont. Shelf Res. 18: 1311-1331.

EismA, D. 1981. Supply and deposition of suspended matter in the North Sea. Special Publication Int. Ass. Sediment 5: 415-428.

Fuhrman, J. A., K. MacCallum, and A. A. Davis. 1992. Novel major archaebacterial group from marine plankton. Nature 356: $148-149$.

Hedges, J. I., R. G. Keil, And R. Benner. 1997. What happens to terrestrial matter in the ocean? Org. Geochem. 27: 195-212.

—, AND F. G. Prahl. 1993. Early diagenesis: Consequences for applications of molecular biomarkers, p. 237-253. In $\mathrm{M}$. H. Engel and S. A. Macko [eds.], Organic geochemistryprinciples and applications. Plenum.

Herndl, G. J., T. Reinthaler, E. Teira, H. van Aken, C. Veth, A. Pernthaler, and J. Pernthaler. 2005. Contribution of Archaea to total prokaryotic production in the deep Atlantic Ocean. Appl. Environ. Microbiol. 71: 2303-2309.
Hoefs, M. J. L., J. S. Sinninghe Damsté, G. J. De Lange, and J. W. DE LeEuw. 1998. Changes in kerogen composition across an oxidation in Madeira abyssal plain turbidites by pyrolysis GC-MS, p. 591-607. In P. P. E. Weaver, H.-U. Schmincke, J. V. Firth, and W. Duffield [eds.], Proceedings of the Ocean Drilling Program, Scientific Results, v. 157.

Hopmans, E. C., J. W. H. Weijers, E. Schefub, L. Herfort, J. S. Sinninghe Damsté, and S. Schouten. 2004. A novel proxy for terrestrial organic matter in sediments based on branched and isoprenoid tetraether lipids. Earth Planet. Sci. Lett. 224: 107-116.

Karner, M. B., E. F. DeLong, and D. M. Karl. 2001. Archaeal dominance in the mesopelagic zone of the Pacific Ocean. Nature 409: 507-510.

Kwatd, F. J. P. M. 1991. Summer and winter regimes of runoff generation and soil-erosion on cultivated loess soils (The Netherlands). Earth Surf. Proc. Landf. 16: 653-662.

LeE, A. J. 1980. North Sea: Physical oceanography, p. 467-493. In F. T. Banner, M. B. Collins, and K. S. Massie [eds.], The north-west European shelf seas: The sea bed and the sea in motion. II. Physical and chemical oceanography, and physical resources. Elsevier.

Megens, L., J. van der Plicht, and J. W. De Leeuw. 2001. Temporal variations in ${ }^{13} \mathrm{C}$ and ${ }^{14} \mathrm{C}$ concentrations in particulate organic matter from the southern North Sea. Geochim. Cosmochim. Acta 65: 2899-2911.

Meyers, P. A. 1994. Preservation of elemental and isotopic source identification of sedimentary organic matter. Chem. Geol. 114: 289-302.

Otto, L., J. T. F. Zimmerman, G. K. Furnes, M. Mork, R. SAetre, AND G. BECKER. 1990. Review of the physical oceanography of the North Sea. Neth. J. Sea Res. 26: 161-238.

Pancost, R. D., And C. S. Boot. 2004. The palaeoclimatic utility of terrestrial biomarkers in marine sediments. Mar. Chem. 92: 239-261.

Powers, L. A., J. P. Werne, T. C. Johnson, E. C. Hopmans, J. S. Sinninghe Damsté, and S. Schouten. 2004. Crenarchaeotal membrane lipids in lake sediments: A new paleotemperature proxy for continental paleoclimate reconstruction? Geology 32: 613-616.

Prahl, F. G., G. J. De Lange, S. Scholten, and G. L. Cowie. 1997. A case of post-depositional aerobic degradation of terrestrial organic matter in turbidite deposits from the Madeira abyssal plain. Org. Geochem. 27: 141-152.

SAlomons, W., AND W. G. Mook. 1981. Field observations of the isotopic composition of particulate organic carbon in the southern North Sea and adjacent estuaries. Mar. Geol. 41: M11-M20.

Schlesinger, W. H., and J. M. Melack. 1981. Transport of organic carbon in the worlds rivers. Tellus 33: 172-187.

Schouten, S., E. C. Hopmans, R. D. Pancost, and J. S. Sinninghe DAMSTÉ. 2000. Widespread occurrence of structurally diverse tetraether membrane lipids: Evidence for the ubiquitous presence of low-temperature relatives of hyperthermophiles. Proc. Natl. Acad. Sci. USA 97: 14421-14426.

Sinninghe Damsté, J. S., S. Schouten, E. C. Hopmans, A. T. Van Duin, and J. A. J. Geenevasen. 2002. Crenarchaeol: The characteristic core glycerol dibiphytanyl glycerol tetraether membrane lipid of cosmopolitan pelagic crenarchaeota. J. Lipids Res. 43: 1641-1651.

VAN DiJK, P. M., AND F. J. P. M. KwAAD. 1996. Runoff generation and soil erosion in small agricultural catchments with Loessderived soils. Hydro. Process 10: 1049-1059.

van RaAphorst, W., H. Malschaert, and H. Van Haren. 1998. Tidal resuspension and deposition of particulate matter in the Oyster Grounds, North Sea. J. Mar. Res. 56: 257-291. 
Visser, M., W. P. M. de Ruijter, and L. Postma. 1991. The distribution of suspended matter in the Dutch coastal zone. Neth. J. Sea Res. 27: 127-143.

Weijers, J. W. H., S. Schouten, E. C. Hopmans, J. A. J. Geenevasen, O. R. P. David, J. M. Coleman, R. D. Pancost, And J. S. Sinninghe Damsté. 2006. Membrane lipids of mesophilic anaerobic bacteria thriving in peats have typical archaeal traits. Environ. Microbiol. 8: 648-657. - - M. van der Linden, B. van Geel, AND J. S. Sinninghe DAmsté. 2004. Water table related variations in the abundance of intact archaeal membrane lipids in a Swedish peat bog. FEMS Microbiol. Lett. 239: 51-56.
O. C. Spaargaren, and J. S. Sinninghe Damsté. In press. Occurrence and distribution of tetraethers membrane lipids in soils: Implication for the use of the TEX86 proxy and the BIT index. Organic Geochemistry.

Wells, L. E., M. Cordray, S. Bowerman, L. A. Miller, W. F Vincent, And J. W. Deming. 2006. Archaea in particles-rich waters of the Beaufort Shelf and Franklin Bay, Canadian Arctic: Clues to an allochthonous origin? Limnol. Oceanogr. 51: $47-59$.

Received: 26 September 2005 Accepted: 13 March 2006 Amended: 27 March 2006 